\title{
Halorubrum xinjiangense sp. nov., a novel halophile isolated from saline lakes in China
}

Correspondence

Shuang-Jiang Liu

shuangjiang@hotmail.com

\author{
Jie Feng, Pei-Jin Zhou and Shuang-Jiang Liu \\ Institute of Microbiology, Chinese Academy of Sciences, Beijing 100080, PR China
}

\begin{abstract}
A novel halophilic archaeon, strain BD-1 ${ }^{\top}$, was isolated from Xiao-Er-Kule Lake in Xinjiang, China. The taxonomy of strain $\mathrm{BD}-1^{\top}$ was studied by polyphasic methods. According to $16 \mathrm{~S}$ rRNA gene sequence similarity, strain $\mathrm{BD}-1^{\top}$ was phylogenetically related to Halorubrum trapanicum (98.4\%), Halorubrum sodomense (98.0\%), Halorubrum distributum (97.8\%) and Halorubrum coriense $(97 \cdot 3 \%)$. Strain $B D-1^{\top}$ is able to grow at $10^{\circ} \mathrm{C}$ and further differs physiologically from the above species in the assimilation of sugars. The $\mathrm{G}+\mathrm{C}$ content of DNA is $68.0 \%\left(T_{m}\right)$. The DNA-DNA relatedness values to Hrr. trapanicum and Hrr. distributum are 47 and $24 \%$, respectively. It is concluded that strain $B D-1^{\top}$ represents a novel species of the genus Halorubrum, for which the name Halorubrum xinjiangense sp. nov. is proposed. The type strain is $B D-1^{\top}\left(=\right.$ AS $\left.1.3527^{\top}=J C M ~ 12388^{\top}\right)$.
\end{abstract}

Members of the genus Halorubrum (McGenity \& Grant, 1995) are widely distributed in hypersaline environments such as salt and/or soda lakes and solar salterns (Ochsenreiter et al., 2002, as cited therein). Being fastgrowing species and active in the conversion of sugars and amino acids, Halorubrum species are considered to play important roles in the carbon and nitrogen cycles of hypersaline environments. Currently, the genus Halorubrum contains nine species with validly published names: Halorubrum sodomense (Oren, 1983), Halorubrum lacusprofundi (Franzmann et al., 1988), Halorubrum saccharovorum (Tomlinson \& Hochstein, 1976), Halorubrum trapanicum, Halorubrum coriense (Kamekura \& DyallSmith, 1995), Halorubrum distributum, Halorubrum vacuolatum (Kamekura et al., 1997; Grant \& Larsen, 1989), Halorubrum tebenquichense (Lizama et al., 2002) and Halorubrum tibetense (Fan et al., 2004).

Strain BD- $1^{\mathrm{T}}$ was isolated from sludge samples of XiaoEr-Kule saline lake in Xinjiang, China, by enrichment and subsequent plating of the enriched cultures on agar medium containing the following ingredients $\left(1^{-1}\right)$ : Casamino acids, $1 \mathrm{~g}$; yeast extract, $1 \mathrm{~g}$; trisodium citrate, $3 \mathrm{~g} ; \mathrm{NaCl}, 200 \mathrm{~g}$; $\mathrm{KCl}, 2 \mathrm{~g} ; \mathrm{MgSO}_{4} .7 \mathrm{H}_{2} \mathrm{O}, 5 \mathrm{~g} ; \mathrm{MnSO}_{4} .7 \mathrm{H}_{2} \mathrm{O}, 0.2 \mathrm{mg}$; $\mathrm{FeSO}_{4} \cdot 7 \mathrm{H}_{2} \mathrm{O}, 0.05 \mathrm{~g}$; glucose, $10 \mathrm{~g}$ ( $\mathrm{pH}$ adjusted to $7 \cdot 0$ with $1 \mathrm{M} \mathrm{NaOH}$ solution). This strain grew over a temperature range of $10-54^{\circ} \mathrm{C}$ (optimum $40^{\circ} \mathrm{C}$ ) as determined by using a temperature gradient incubator and over a $\mathrm{pH}$ range of $6 \cdot 0-10 \cdot 0$ (optimum $7 \cdot 0-7 \cdot 5$ ) as determined with

Published online ahead of print on 13 April 2004 as DOI 10.1099/ ijs.0.63209-0.

The GenBank/EMBL/DDBJ accession number for the 16S rRNA gene sequence of strain $B D-1^{\top}$ is $A Y 510707$. various $\mathrm{pH}$ buffers. Routine cultivation was conducted at $40{ }^{\circ} \mathrm{C}$ and $\mathrm{pH} 7 \cdot 5$. The requirements for $\mathrm{NaCl}$ and magnesium for growth were determined in media with $0 \cdot 9-5 \cdot 2 \mathrm{M} \mathrm{NaCl}$ or $0-0 \cdot 5 \mathrm{M} \mathrm{MgSO}_{4}$.

Phenotypic tests were performed according to the proposed minimal standards for the description of new taxa in the order Halobacteriales (Oren et al., 1997). Cell motility and morphology were examined by phase-contrast and transmission electron microscopy of exponentially growing liquid cultures. Gram staining was carried out as described by Dussault (1955). Colony morphology was observed on optimal growth agar medium after incubation at $40{ }^{\circ} \mathrm{C}$ for 4 days. Anaerobic growth was tested in the presence of $5 \mathrm{~g}$ potassium nitrate, L-arginine or DMSO $1^{-1}$ in filled, stoppered tubes. Tests for catalase and oxidase activities and hydrolysis of starch and Tween 80 were performed as described previously (Gonzalez et al., 1978). Nitrate reduction, $\mathrm{H}_{2} \mathrm{~S}$ formation, indole formation and the utilization of sugars, alcohols, amino acids and organic acids were examined as described by Oren et al. (1997). Phospholipids and glycolipids were separated on silica gel plates $(10 \times 10 \mathrm{~cm})$ by TLC and were analysed according to Kamekura et al. (1997) and Xin et al. (2001).

DNA base composition was determined by thermal denaturation $\left(T_{\mathrm{m}}\right)$. The $16 \mathrm{~S} \mathrm{rRNA}$ gene sequence was amplified with archaeon-specific primers under conditions described previously (Zhang et al., 2003). 16S rRNA gene sequence alignments were performed by using CLUSTAL $\mathrm{W}$ version 1.3b (Van de Peer \& De Wachter, 1994). A phylogenetic tree (Fig. 1) was constructed by the neighbour-joining method with Kimura's two-parameter calculation model in TREECON $\mathrm{W}$ version 1.3b. DNA-DNA hybridizations of strain $\mathrm{BD}-1^{\mathrm{T}}$ to the type strains of Hrr. trapanicum and Hrr. 


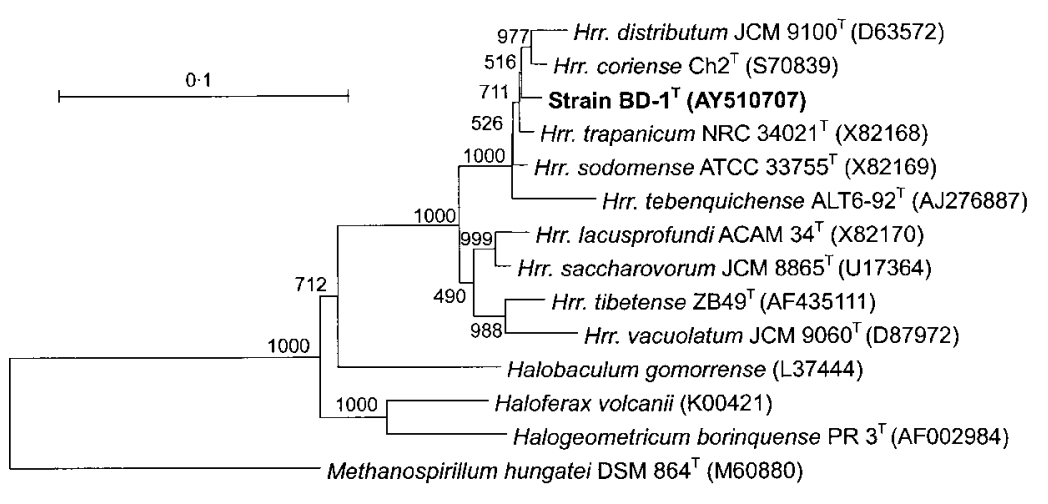

Fig. 1. Phylogenetic tree showing the position of strain BD-1 $1^{\top}$ among the species of genus Halorubrum and other genera of extremely halophilic archaea. The 16S rRNA gene sequence of Methanospirillum hungatei DSM $864^{\top}$ was used as outgroup. Numbers at branch points indicate the level of bootstrap support, based on 1000 resamplings. distributum were performed by thermal denaturation and the renaturation method of De Ley et al. (1970) as modified by Huß et al. (1983).

Strain BD- $1^{\mathrm{T}}$ contained $\mathrm{C}_{20} \mathrm{C}_{20}$ derivatives of phosphatidylglycerol, phosphatidylglycerol phosphate methyl ester, phosphatidylglycerol sulfate and sulfated mannosyl-glucosyl glycerol diether. The lipid composition, physiological properties and characteristics of the DNA molecule indicated that strain $\mathrm{BD}-1^{\mathrm{T}}$ was a member of the genus Halorubrum. $16 \mathrm{~S}$ rRNA gene sequence similarity searches indicated that strain $\mathrm{BD}-1^{\mathrm{T}}$ was phylogenetically related to Hrr. trapanicum $(98 \cdot 4 \%)$, Hrr. sodomense (98.0\%), Hrr. distributum (97.8\%) and Hrr. coriense (97.3\%). However, they differed in phenotypic and physiological properties. Strain BD-1 ${ }^{\mathrm{T}}$ grew at $10^{\circ} \mathrm{C}$, while neither $\mathrm{Hrr}$. trapanicum nor $\mathrm{Hrr}$. sodomense grew at this temperature. Strain $\mathrm{BD}-1^{\mathrm{T}}$ assimilated glucose, sucrose, fructose and maltose, but not lactose, galactose or glycerol. Detailed phenotypic and physiological properties of this strain are given in the species description, and differentiating characteristics of this strain $\mathrm{BD}-1^{\mathrm{T}}$ from other Halorubrum species are listed in Table 1.

Members of the genus Halorubrum gathered into three main clusters based on $16 \mathrm{~S}$ rRNA gene sequence similarities, with $100 \%$ bootstrap support (Grant \& Larsen, 1989). Cluster 1 contains Hrr. saccharovorum and Hrr. lacusprofundi (with similarity of $98 \cdot 3 \%$ ). Cluster 2 contains Hrr. sodomense, Hrr. trapanicum, Hrr. coriense and Hrr. distributum (with similarity $>97 \cdot 7 \%$ ). Cluster 3 is phylogenetically distant

Table 1. Differentiation of Halorubrum xinjiangense sp. nov. from other Halorubrum species

Species: 1, Hrr. xinjiangense sp. nov.; 2, Hrr. saccharovorum; 3, Hrr. coriense; 4, Hrr. distributum; 5, Hrr. lacusprofundi; 6, Hrr. sodomense; 7, Hrr. trapanicum; 8, Hrr. vacuolatum; 9, Hrr. tebenquichense. ND, Not described; PGS, phosphatidylglycerol sulfate; S-DGD, sulfated mannosyl-glucosyl glycerol diether.

\begin{tabular}{|llllllllll|}
\hline Property & $\mathbf{1}$ & $\mathbf{2}$ & $\mathbf{3}$ & $\mathbf{4}$ & $\mathbf{5}$ & $\mathbf{6}$ & $\mathbf{7}$ & $\mathbf{8}$ & $\mathbf{9}$ \\
\hline Motility & + & + & + & + & $\mathrm{ND}$ & + & - & - & - \\
Gas vacuole & - & - & - & - & - & - & - & + & - \\
Growth at 2 M NaCl & + & + & - & + & + & + & - & - & + \\
$\mathrm{Mg}^{2+}$ required & - & + & + & $\mathrm{ND}$ & + & + & $\mathrm{ND}$ & - & - \\
Growth at $10{ }^{\circ} \mathrm{C}$ & + & - & - & - & + & - & - & - & - \\
Growth at pH 10·5 & - & - & - & - & - & - & - & + & - \\
Starch hydrolysis & - & - & $\mathrm{ND}$ & - & - & + & - & $\mathrm{ND}$ & - \\
Indole production & - & - & - & - & - & - & - & $\mathrm{ND}$ & - \\
Sugar assimilation: & & & & & & & & & \\
$\quad$ Glucose & + & + & + & - & + & + & + & + & + \\
Sucrose & + & + & + & - & $\mathrm{ND}$ & + & + & + & - \\
$\quad$ Lactose & - & + & + & $\mathrm{ND}$ & + & + & - & $\mathrm{ND}$ & - \\
$\quad$ Fructose & + & + & $\mathrm{ND}$ & - & - & + & + & - & + \\
Galactose & - & + & $\mathrm{ND}$ & - & + & - & + & + & + \\
$\quad$ Maltose & + & + & $\mathrm{ND}$ & - & - & + & + & - & - \\
Glycerol assimilation & - & + & + & + & - & + & + & - & + \\
Amino acids required & - & + & - & $\mathrm{ND}$ & + & + & + & + & - \\
Presence of PGS & + & + & + & + & + & + & + & - & - \\
Presence of S-DGD & + & + & + & + & + & + & + & - & + \\
G+C content (mol\%) & $68 \cdot 0$ & $71 \cdot 2$ & $\mathrm{ND}$ & $63 \cdot 6$ & $65 \cdot 3$ & $67 \cdot 4$ & $64 \cdot 3$ & $62 \cdot 7$ & $63 \cdot 2$ \\
\hline
\end{tabular}


from the above two clusters and contains Hrr. vacuolatum. The recent discovery of Hrr. tebenquichense (Lizama et al., 2002), Hrr. tibetense (Fan et al., 2004) and strain BD-1 ${ }^{\mathrm{T}}$ (Hrr. xinjiangense sp. nov.) significantly reduced the bootstrap support (49\%) of clusters 1 and 3 (Fig. 1), while cluster 2 is still supported by $100 \%$ bootstrap. Strain $\mathrm{BD}-1^{\mathrm{T}}$ clearly belongs to cluster 2, and the closest relative was Hrr. trapanicum $(98 \cdot 4 \%)$. The DNA-DNA relatedness of strain $\mathrm{BD}-1^{\mathrm{T}}$ to Hrr. trapanicum and Hrr. distributum was 47 and $24 \%$, respectively.

\section{Description of Halorubrum xinjiangense sp. nov.}

Halorubrum xinjiangense (xin.ji.ang.en'se. N.L. neut. adj. xinjiangense pertaining to Xinjiang, where the strain was isolated).

Cells are short rods $(0 \cdot 8-1 \cdot 2 \times 1 \cdot 8-2 \cdot 6 \mu \mathrm{m})$ and Gramnegative. Colonies on agar plates containing $25 \%(\mathrm{w} / \mathrm{v})$ total salts are red, elevated and round. Chemo-organotrophic and aerobic. Growth occurs at $2 \cdot 0-5 \cdot 2 \mathrm{M} \mathrm{NaCl}, \mathrm{pH}$ 6-10 and $10-54^{\circ} \mathrm{C}$, with optimal growth at $3 \cdot 1-3 \cdot 4 \mathrm{M} \mathrm{NaCl}$, $\mathrm{pH} 7 \cdot 0-7 \cdot 5$ and $40^{\circ} \mathrm{C}$. Magnesium is not required for growth. Catalase and oxidase are positive. Anaerobic growth with nitrate, arginine and DMSO does not occur and nitrate reduction to nitrite or dinitrogen is not observed. $\mathrm{H}_{2} \mathrm{~S}$ is produced from cysteine, but indole formation is negative. Tween 80 and starch are not hydrolysed. Amino acids are not required for growth. Fructose, glucose, sucrose and maltose are utilized with production of acids. No growth or acid production is observed on mannose, lactose, raffinose, rhamnose, galactose, D-ribose, glycerol, mannitol or sorbitol. Organic acids are not utilized. Cells contain $\mathrm{C}_{20} \mathrm{C}_{20}$ derivatives of phosphatidylglycerol, phosphatidylglycerol phosphate methyl ester, phosphatidylglycerol sulfate and sulfated mannosyl-glucosyl glycerol diether. The $\mathrm{G}+\mathrm{C}$ content of DNA is $68 \cdot 0 \%\left(T_{\mathrm{m}}\right)$.

The type strain is $\mathrm{BD}-1^{\mathrm{T}}\left(=\mathrm{AS} 1.3527^{\mathrm{T}}=\mathrm{JCM} 12388^{\mathrm{T}}\right)$, isolated from Xiao-Er-Kule Lake in Xinjiang, China.

\section{Acknowledgements}

This work was supported by grants from the Chinese Academy of Sciences (KJCX1-SW-07). We appreciate the careful reading and modification of this paper by Dr K. Warren-Rhodes at the University of California (Berkeley). We express our thanks to Mr Y.-G. Zhou for his help with the deposit of strain $\mathrm{BD}-1^{\mathrm{T}}$ in culture collections.

\section{References}

De Ley, J., Cattoir, H. \& Reynaerts, A. (1970). The quantitative measurement of DNA hybridization from renaturation rates. Eur J Biochem 12, 133-142.

Dussault, H. P. (1955). An improved technique for staining halophilic bacteria. J Bacteriol 70, 484-485.

Fan, H., Xue, Y., Ma, Y., Ventosa, A. \& Grant, W. D. (2004) Halorubrum tibetense sp. nov., a novel haloalkaliphilic archaeon from Lake Zabuye in Tibet, China. Int J Syst Evol Microbiol 54, 1213-1216.
Franzmann, P. D., Stackebrandt, E., Sanderson, K., Valkman, K., Cameron, D. E., Stevenson, P. L., McMeekin, T. A. \& Burton, H. R. (1988). Halobacterium lacusprofundi sp. nov., a halophilic bacterium isolated from Deep Lake, Antarctica. Syst Appl Microbiol 11, 20-27.

Gonzalez, C., Gutierrez, C. \& Ramirez, C. (1978). Halobacterium vallismortis sp. nov. An amylolytic and carbohydrate-metabolizing, extremely halophilic bacterium. Can J Microbiol 24, 710-715.

Grant, W. D. \& Larsen, H. (1989). Group III. Extremely halophilic archaebacteria. Order Halobacteriales ord. nov. In Bergey's Manual of Systematic Bacteriology, vol. 3, pp. 2216-2219. Edited by J. T. Staley, M. P. Bryant, N. Pfennig \& J. G. Holt. Baltimore: Williams \& Wilkins.

Huß, V. A. R., Festl, H. \& Schleifer, K. H. (1983). Studies on the spectrometric determination of DNA hybridization from renaturation rates. Syst Appl Microbiol 4, 184-192.

Kamekura, M. \& Dyall-Smith, M. L. (1995). Taxonomy of the family Halobacteriaceae and the description of two new genera Halorubrobacterium and Natrialba. J Gen Appl Microbiol 41, 333-350.

Kamekura, M., Dyall-Smith, M. L., Upasani, V., Ventosa, A. \& Kates, M. (1997). Diversity of alkaliphilic halobacteria: proposals for transfer of Natronobacterium vacuolatum, Natronobacterium magadii, and Natronobacterium pharaonis to Halorubrum, Natrialba, and Natronomonas gen. nov., respectively, as Halorubrum vacuolatum comb. nov., Natrialba magadii comb. nov., and Natronomonas pharaonis comb. nov., respectively. Int J Syst Bacteriol 47, 853-857.

Lizama, C., Monteoliva-Sánchez, M., Suárez-García, A., RossellóMora, R., Aguilera, M., Campos, V. \& Ramos-Cormenzana, A. (2002). Halorubrum tebenquichense sp. nov, a novel halophilic archaeon isolated from the Atacama Saltern, Chile. Int J Syst Evol Microbiol 52, 149-155.

McGenity, T. J. \& Grant, W. D. (1995). Transfer of Halobacterium saccharovorum, Halobacterium sodomense, Halobacterium trapanicum NRC 34021 and Halobacterium lacusprofundi to the genus Halorubrum gen. nov., as Halorubrum saccharovorum comb. nov., Halorubrum sodomense comb. nov., Halorubrum trapanicum comb. nov., and Halorubrum lacusprofundi comb. nov. Syst Appl Microbiol 18, 237-243.

Ochsenreiter, T., Pfeifer, F. \& Schleper, C. (2002). Diversity of archaea in hypersaline environments characterized by molecularphylogenetic and cultivation studies. Extremophiles 6, 267-274.

Oren, A. (1983). Halobacterium sodomense sp. nov., a Dead Sea halobacterium with an extremely high magnesium requirement. Int $J$ Syst Bacteriol 33, 381-386.

Oren, A., Ventosa, A. \& Grant, W. D. (1997). Proposed minimal standards for description of new taxa in the order Halobacteriales. Int J Syst Bacteriol 47, 233-238.

Tomlinson, G. A. \& Hochstein, L. I. (1976). Halobacterium saccharovorum sp. nov., a carbohydrate-metabolizing, extremely halophilic bacterium. Can J Microbiol 22, 587-591.

Van de Peer, Y. \& De Wachter, R. (1994). TREECON for Windows: a software package for the construction and drawing of evolutionary trees for Microsoft Windows environment. Comput Appl Biosci 10, 569-570.

Xin, H., Itoh, T., Zhou, P., Suzuki, K. \& Nakase, T. (2001). Natronobacterium nitratireducens sp. nov., a haloalkaliphilic archaeon isolated from a soda lake in China. Int J Syst Evol Microbiol 51, 1825-1829.

Zhang, D., Yang, H., Zhang, W., Huang, Z. \& Liu, S.-J. (2003). Rhodocista pekingensis sp. nov., a cyst-forming phototrophic bacterium from a municipal wastewater treatment plant. Int J Syst Evol Microbiol 53, 1111-1114. 